\title{
Valorization of Blueberry By-Products (Vaccinium spp.): Antioxidants by Pressurized Liquid Extraction (PLE) and Kinetics Models
}

\author{
Maiara Cristina Secco ${ }^{1(\mathbb{D})}$, Bruno Fischer ${ }^{1(\mathbb{D})}$, Ilizandra Aparecida Fernandes ${ }^{1(\mathbb{D})}$, \\ Rogério Luis Cansian ${ }^{1}$ (D), Natalia Paroul ${ }^{1}$ (D), Alexander Junges 1,*iD \\ 1 Department of Food Engineering; URI - Erechim Av. Sete de Setembro; 1621; Erechim; Rio Grande do Sul; Brazil; 99709 - \\ 910, Brazil \\ * Correspondence: junges@uricer.edu.br;
}

Scopus Author ID 18434067000

Received: 19.04.2021; Revised: 25.05.2021; Accepted: 27.05.2021; Published: 9.06.2021

\begin{abstract}
Blueberry by-products are rich in bioactive compounds with antioxidant properties, such as phenolic compounds and anthocyanins. Pressurized liquid extraction (PLE) is an alternative to traditional methods in the obtention of bioactive compounds and can adjust pressure and temperature conditions to regulate the solubility of target compounds in the solvent. In this context, this study aimed to evaluate different solvents in the extraction of the compounds, antioxidants from the blueberry byproducts obtained by using the PLE technique and evaluating Weibull and power-law models in the kinetics for extraction yield, total phenolic content (TPC), and monomeric anthocyanin content (MAC). Extract yields of 31.33 to $48.98 \%(\mathrm{~m} / \mathrm{m})$ were obtained. The highest yield was obtained using ethylene glycol 20\% (v/v). The extracts present TPC between 3541.62 and $4116.62 \mathrm{mg} \mathrm{GAE} / 100 \mathrm{~g} \mathrm{dr}$, the propylene glycol $20 \%(\mathrm{v} / \mathrm{v})$ presented the highest content. The extracts present a MAC between 801.06 and $1036.65 \mathrm{mg} \mathrm{C} 3 \mathrm{CE} / 100 \mathrm{~g} \mathrm{dr}$, the methanol presented the highest content. The best antioxidant activity was demonstrated by the extract obtained using propylene glycol $20 \%$ (v/v) as a solvent, with $\mathrm{IC}_{50}$ of the $0.11 \mathrm{mg} / \mathrm{mL}$, justified by the higher content of extracted phenolic compounds. All extracts presented good antioxidant activity, and the PLE technique can be used to obtain biocomposites blueberry by-products.
\end{abstract}

Keywords: total phenolic; monomeric anthocyanin; antioxidant activity; Weibull model; mathematical modeling.

(C) 2021 by the authors. This article is an open-access article distributed under the terms and conditions of the Creative Commons Attribution (CC BY) license (https://creativecommons.org/licenses/by/4.0/).

\section{Introduction}

European wild blueberry or bilberry is a small fruit, belongs to the Vaccinium genus and originally from North America and Europe [1]. The production of blueberries in the world, from 1994 to 2019, was 823.3 thousand tons [2]. It has a high content of bioactive compounds in its composition, with actions of interest for the food and pharmaceutical industry, known as "fruit of longevity" [3, 4].

A large amount of blueberry is processed because it is a seasonal fruit, generating waste from the process. In the juice industry, the blueberry pomace or by-products are generated, composed of skin, seeds, and pulp residue. Without a proper destination, this waste ends up being sent to compost or animal feed. However, bioactive compounds, such as polyphenols, remain retained in the by-products [1]. The United Nations Food and Agriculture Organization 
(FAO) has estimated that more than $30 \%$ of global food production is discarded as a by-product or waste [5].

The anthocyanins present in the fruit's peel, such as blueberry, are an interesting natural pigment source, with a blue, purple, or red hue. Anthocyanins have antioxidant capacity and other phenolic compounds present in these residues [6]. The group of phenolics demonstrates antimicrobial effects and other beneficial biological properties, including anti-inflammatory, antioxidant, and anti-diabetic. Blueberry is a source of various phenolic compounds like flavonoids, phenolic acids, lignans, and polymeric tannins [7].

Most bioactive compounds are sensitive to temperature, luminosity, and $\mathrm{pH}$. Due to these factors, a form of extraction that does not cause degradation is sought. The extraction efficiency is closely linked to the extraction temperature and the characteristics of the solvent used, such as polarity, which can affect the transfer of electrons and hydrogen atoms [8].

An alternative to conventional Soxhlet extraction, infusion, maceration, and steam distillation methods is pressurized liquid extraction (PLE), also known as accelerated solvent extraction (ASE), which has some advantages, such as reduce extraction time and lower solvent consumption. PLE is a clean technology with the possibility of adjusting process selectivity parameters to a group of compounds to be extracted. The pressure and temperature conditions regulate the solubility of target compounds in the solvent and the desorption kinetics from solid matrices $[9,10]$.

Several studies using PLE for the bioactive compounds recovery from natural sources, mainly from wastes, such as by-products, skins, leaves, and pomaces, have been developed. Among these studies, we have extractions of the mulberry leaves [11], citrus by-products [12], avocado peel by-product [13], cocoa bean shell [14], mango seed kernel [15], olive leaves [16], rowanberry pomace [17], rosemary leaves [18], pomegranate peel [19], lingonberry pomace [20], sweet cherry stems [21], grape marc [22], cranberry pomace [23], araçazeiro leaf [24], feijoa leaf [25], passion fruit rinds [26], apple pomace [27, 28], yerba mate leaves [29] and red wine pomace [30] to obtention bioactive compounds.

In this context, this study aimed to evaluate different solvents in the extraction of the antioxidant compounds from the blueberry by-products obtained by using the pressurized liquid extraction (PLE) technique and evaluating Weibull and power-law models in the kinetics for extraction yield, total phenolic content (TPC) and monomeric anthocyanin content (MAC).

\section{Materials and Methods}

\subsection{Raw material and chemicals.}

The by-products of frozen blueberry, containing seeds, skins, and pulp residue, is generated after the juice was extracted, was donated by Orgânicos Prérola da Terra (Antônio Prado, RS, Brazil). The blueberry by-products were dried in a freeze-dryer (Modulyo, Edwards) coupled to a vacuum pump (RV8, Edwards). Samples were lyophilized in Petri plates for $48 \mathrm{~h}$ at $-40^{\circ} \mathrm{C}$. After drying, the by-products of blueberry were separated by sieves and ground in a knife mill (MA048, Marconi). The particle size of the starting material was between 30 and 60 mesh $(600-250 \mu \mathrm{m})$. The solvents used were ethanol (99.9\%, Merck Millipore Germany) $95 \%$ (v/v) in distilled water, absolute methanol (99.5\%, Neon - Brazil), propylene glycol (99.5\%, Merck Millipore - Germany) $20 \%$ in aqueous solution (v/v) and ethylene glycol (99.9\%, Merck Millipore - Germany) $20 \%$ in aqueous solution (v/v). 


\subsection{Blueberry by-products characterization.}

The blueberry by-products used as feedstock was characterized according to Instituto Adolfo Lutz methods [31], for soluble solids (315/IV), total acidity (016/IV), pH (017/IV), and moisture in infrared moisture analyzer (ID-50, Marte) as described by Garcia-Amoedo and Almeida-Muradian [32].

\subsection{Pressurized liquid extraction (PLE).}

\subsubsection{Extraction apparatus.}

The pressurized liquid extraction system (Figure 1) consists of a circulation bath (1) for temperature control, a solvent reservoir (2), a liquid pump (3), a shut-off valve (4), a pressure indicator manometer (5), an extraction cell (6) and a pressure regulating valve (7) where the extracts were collected.

Approximately $17 \mathrm{~g}$ of the sample was added to the extractor cell, which was closed and mounted in the temperature control system. The pump conducts the solvent of the reservoir in the selected flow rate and pressurizes the system. Extraction begins when the system reaches the set temperature and pressure.

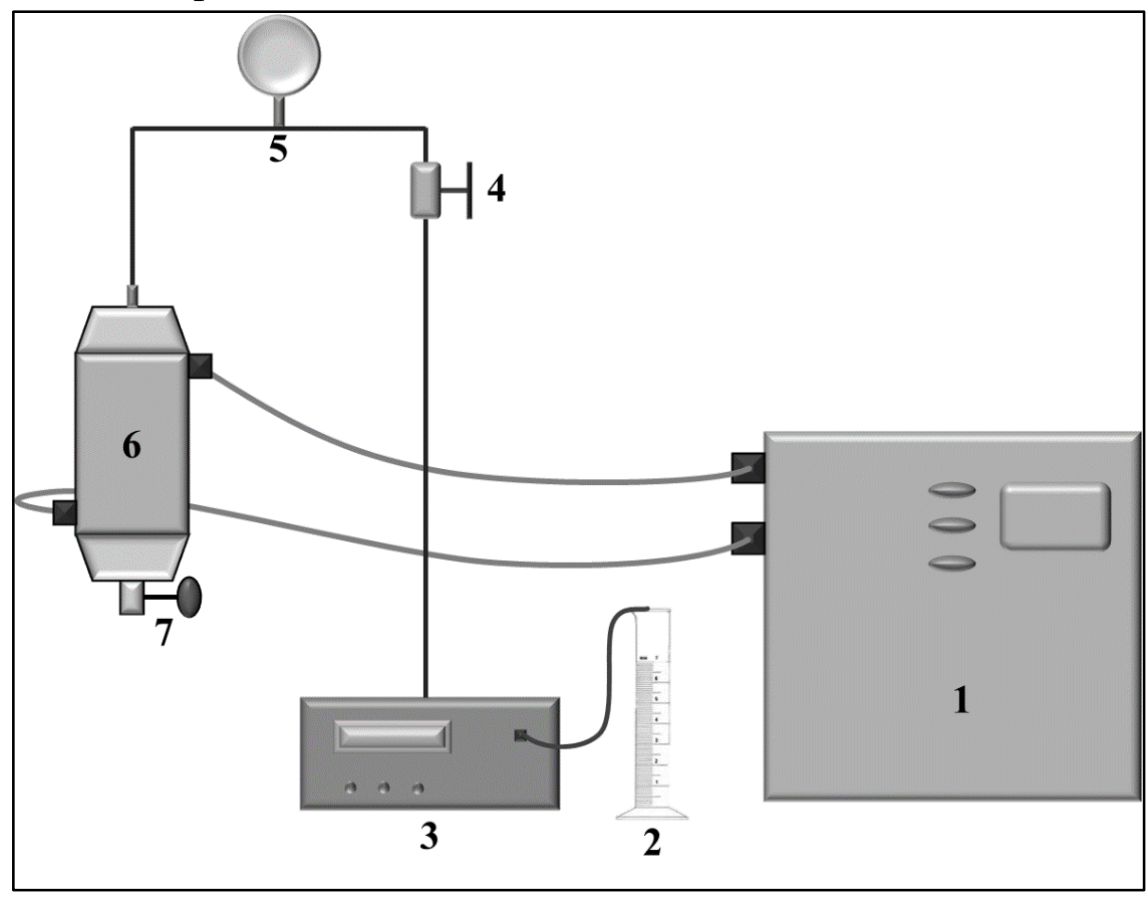

Figure 1. Pressurized liquid extraction system.

\subsubsection{Extraction conditions.}

The extraction procedures were based on the study of Paes et al. [10] with adaptations. The temperature used was $40^{\circ} \mathrm{C}$, pressure $100 \mathrm{bar}$, and solvent flow rate $2 \mathrm{~mL} / \mathrm{min}$. The system remained pressurized for $30 \mathrm{~min}$ in the static extraction, followed by a further $180 \mathrm{~min}$ of dynamic extraction.

\subsubsection{Determination of the overall yield.}

The yield curves for the PLE extraction procedure were calculated (Eq. 1) as the ratio between the mass of total extract (crude extract) and the mass of the raw material loaded in the extraction vessel. 
Extract Yield $(m g / g)=M_{E} /_{M_{S}}$

where $M_{E}$ is the total mass of extract obtained and $M_{S}$ is the mass of sample used for extraction. The extracts were collected at the times of 1, 2, 3, 5, 7, 10, 15, 20, 30, 40, 50, 60, $70,85,100,120,140,160$, and 180 min to build the global yield curves.

\subsection{Characterization of the extracts.}

2.4.1. Total phenolic content (TPC).

Quantification of the total phenolic content (TPC) present in the extracts was done by the method of Folin-Ciocalteau, described by Singleton and Rossi [33]. A standard curve was plot using gallic acid as a reference, with concentrations between 0.01 and $0.1 \mathrm{mg} / \mathrm{mL}$, where the equation $(\mathrm{y}=11.94 \mathrm{x}+0.13)$ and the coefficient of determination $\left(\mathrm{R}^{2}=0.9991\right)$ were obtained. The readings were done in a spectrophotometer (UV-1600, Pró-análise) with a wavelength of $760 \mathrm{~nm}$. The assays were run in triplicate, and the results were expressed as $\mathrm{mg}$ gallic acid equivalent (mgGAE)/100 g dry residue (100 g dr).

\subsubsection{Monomeric anthocyanin content (MAC).}

The monomeric anthocyanin content (MAC) present in the extracts was done by the differential $\mathrm{pH}$ method described by Lee et al. [34]. Samples were buffered at pH 1.0 with a solution of potassium chloride and 4.5 with a solution of sodium acetate. The readings were done in a spectrophotometer (UV-1600, Pró-análise) at wavelengths 510 and $700 \mathrm{~nm}$. The total amount of monomeric anthocyanin was calculated by Eq. 2. The results were expressed as mg Cyanidin-3-glucoside equivalent (mgC3GE)/100 g dry residue (100 g dr).

$$
M A C=\frac{\left[\left(A b s_{510}-A b s_{700}\right)_{p H 1.0}-\left(A b s_{510}-A b s_{700}\right)_{p H 4.5}\right] M W * V * D F * 1000}{(\varepsilon * m * 1)}
$$

In Eq. 2, $A b s_{510}$ and $A b s_{700}$ are the absorbances at 510 and $700 \mathrm{~nm}, M W$ represents the molar mass of Cyanidin-3-glucoside $(449.2 \mathrm{~g} / \mathrm{mol}), V$ is the volume of the extract solution $(\mathrm{mL}), D F$ is the conversion of $\mathrm{g}$ to $\mathrm{mg}, \varepsilon$ is the molar extinction coefficient of Cyanidin-3glucoside $(26900 \mathrm{~L} / \mathrm{mol} . \mathrm{cm}), m$ is the sample mass used in the extraction $(\mathrm{g})$, and 1 is the wave path in the cuvette in $\mathrm{cm}$.

\subsubsection{Antioxidant activity.}

The antioxidant activity of the extracts was determined by the DPPH (2,2 diphenyl-1picrylhydrazyl) free radical sequestration method, described by Brand Williams et al. [35]. The extracts were diluted in ethanol at concentrations between 10 and $0.01 \mathrm{mg} / \mathrm{mL}$ and incubated with $0.1 \mathrm{mM}$ DPPH alcoholic solution. The readings were done in a spectrophotometer (UV1600, Pró-análise) with a wavelength of $515 \mathrm{~nm}$. The antioxidant activity was calculated by linear regression and expressed in $\mathrm{IC}_{50}$, representing the concentration required to capture $50 \%$ of the DPPH free radical.

\subsection{Mathematical modeling.}

The PLE extraction kinetics of blueberry by-products, total phenolic content (TPC), and monomeric anthocyanins content (MAC) present in the extracts were modeled in this study 
using the Weibull (Eqs. 3-5) and the power-law models (Eqs. 6, 7). These models were previously proposed in the literature to describe different extraction techniques from different solid matrices. [36-45]. The Weibull model can be represented as:

$$
\begin{aligned}
& \text { Extraction yield, }(\mathrm{mg})_{\text {blueberry extract }} /(g)_{\text {sample mass }}=A \cdot\left(1-\exp \left(-k t^{m}\right)\right) \\
& T P C,(m g)_{G A E} /(100 \mathrm{~g})_{d r}=A \cdot\left(1-\exp \left(-k t^{m}\right)\right) \\
& M A C,(m g)_{C 3 G E} /(100 g)_{d r}=A \cdot\left(1-\exp \left(-k t^{m}\right)\right) \\
& \text { where } t \text { is the extraction time (min), } A, k \text {, and } m \text { are the kinetic parameters. }
\end{aligned}
$$

The power-law model was expressed as:

$$
\begin{aligned}
& \text { Extraction yield, }(\mathrm{mg})_{\text {blueberry extract }} /(\mathrm{g})_{\text {sample mass }}=B \cdot t^{n} \\
& T P C,(\mathrm{mg})_{G A E} /(100 \mathrm{~g})_{d r}=B \cdot t^{n} \\
& M A C,(\mathrm{mg})_{C 3 G E} /(100 \mathrm{~g})_{d r}=B \cdot t^{n}
\end{aligned}
$$

where $t$ is the extraction time $(\mathrm{min}), B$ is a constant incorporating the characteristics of the carrier active agent system, and $n$ is the diffusional exponent. This value is lower than 1 for plant material.

To estimate the kinetic parameters, nonlinear regression was performed by using the software Statistica (version 5.0 - StatSoft). The evaluation of the parameters estimated by the models was performed by minimizing the objective function (OF). Experimental results were then compared with those of the model prediction through the values of the RMSE (Root Mean Square Error) between experimental and calculated represented by Eq. 9:

$$
R M S E=\sqrt{\sum_{i=1}^{N} \frac{\left(y_{\text {exp }}-y_{\text {cal }}\right)^{2}}{N}}
$$

The RMSE quantifies the dispersion of the analyzed and estimated values, where $N$ corresponds to the number of experimental data points in each kinetic curve $\left(y_{\text {exp }}\right)$ the experimental data, and $\left(y_{c a l}\right)$ the calculated. $R M S E$ values closer to zero indicate better model performance.

\subsection{Statistical analyses.}

Statistical analyzes were done on Statistica 5.0 software (StatSoft, Tulsa, USA). The established level of significance was $95 \%(\mathrm{p}<0.05)$, and the means comparison was made by Tukey's test.

\section{Results and Discussion}

\subsection{Characteristics of blueberry by-products.}

The by-products of blueberry had a soluble solids content of $9.50 \pm 0.01{ }^{\circ}$ Brix; total acidity of $0.46 \pm 0.01 \%$ citric acid; $\mathrm{pH}$ of $3.16 \pm 0.10$; and moisture of $65.90 \pm 0.55 \%$.

\subsection{Pressurized liquid extraction (PLE).}

The highest yield of PLE extraction was obtained using ethylene glycol 20\% (43.98\%), while propylene glycol $20 \%$ had the lowest yield (31.33\%) (Table 1). Compared with the 
extraction yield by maceration (8.84\%), the PLE presented extraction yields greater than 3.5 times greater for all solvents used. The total yield shows the efficiency of the solvent in extracting compounds from a plant matrix. Lower results of extract yield $(\%, \mathrm{~m} / \mathrm{m})$ are reported by Paes et al. [10] in the PLE from blueberry by-products using ethanol $(4.2 \% \pm 0.3), 50 \%$ ethanol, and $50 \%$ water $(5.4 \% \pm 0.0)$.

Table 1 presents the total extraction yield, the total phenolic content, the monomeric anthocyanin content, and the antioxidant activity of the extracts for the different solvents used.

Table 1. Total extraction yield, total phenolic content (TPC), monomeric anthocyanin content (MAC), and antioxidant activity of the extracts with differentsolvents.

\begin{tabular}{l|c|c|c|c|c}
\multicolumn{1}{c|}{ Solvent } & $\begin{array}{c}\text { Extract Yield } \\
(\mathbf{m g} / \mathbf{g})\end{array}$ & $\begin{array}{c}\text { Extract Yield } \\
(\mathbf{\%}, \mathbf{m} / \mathbf{m})\end{array}$ & $\begin{array}{c}\text { TPC } \\
(\mathbf{m g}) \mathbf{G A E})(\mathbf{1 0 0} \mathbf{~ g})_{\mathbf{d r}}\end{array}$ & $\begin{array}{c}\text { MAC } \\
(\mathbf{m g}) \mathbf{C 3 G E} /(\mathbf{1 0 0} \mathbf{g})_{\mathbf{d r}}\end{array}$ & $\begin{array}{c}\mathbf{I C}_{\mathbf{5 0}} \\
(\mathbf{m g} / \mathbf{m L})\end{array}$ \\
\hline Ethanol & 337.45 & 33.74 & $3541.62^{\mathrm{d}} \pm 1.65$ & $801.06^{\mathrm{d}} \pm 36.35$ & 0.17 \\
\hline Methanol & 376.90 & 37.69 & $3677.88^{\mathrm{c}} \pm 15.00$ & $1036.65^{\mathrm{a}} \pm 16.05$ & 0.13 \\
\hline Ethylene glycol 20\% & 439.85 & 43.98 & $3820.86^{\mathrm{b}} \pm 6.65$ & $847.25^{\mathrm{c}} \pm 8.97$ & 0.16 \\
\hline Propylene glycol 20\% & 313.39 & 31.33 & $4116.62^{\mathrm{a}} \pm 23.65$ & $953.38^{\mathrm{b}} \pm 23.25$ & 0.11 \\
\hline ME Propylene glycol 20\%* & 88.40 & 8.84 & $968.33^{\mathrm{e}} \pm 8.77$ & $1000.93^{\mathrm{a}} \pm 1.85$ & 5.76
\end{tabular}

Note:*In the best condition of TPC by PLE, extraction by maceration (ME) of (18g) was placed in a glass reactor with 270 $\mathrm{mL}$ of $20 \%$ propylene glycol solvent (v/v), wrapped in aluminum foil, and placed on an orbital shaking at $40^{\circ} \mathrm{C}, 115 \mathrm{rpm}$ shaking, in $180 \mathrm{~min}$.

In relation to TPC, PLE with the propylene glycol $20 \%$ solvent had a higher content, $4116.62 \mathrm{mg} \mathrm{GAE} / 100 \mathrm{~g} \mathrm{dr}$, compared to the other solvents for the same technique. While, in comparison to TPC, by the maceration extraction technique, it obtained $968.33 \mathrm{mg} \mathrm{GAE} / 100 \mathrm{~g}$ $\mathrm{dr}$, the PLE technique presented TPC greater than 4.2 times greater about maceration extraction (ME). Regarding MAC, values were very close in all solvents by PLE (801.06 to $1036.65 \mathrm{mg}$ $\mathrm{C} 3 \mathrm{GE} / 100 \mathrm{~g} \mathrm{dr}$ ), and the same tendency occurs in both extraction techniques.

But, the best result is the one that has the highest antioxidant activity and not the total extract yield. By the PLE technique, excellent values of antioxidant activity ( IC $\left._{50}\right)$ were obtained, from $0.11 \mathrm{mg} / \mathrm{mL}$ by extraction with propylene glycol $20 \%$ to $0.17 \mathrm{mg} / \mathrm{mL}$ with ethanol. As for ME, the antioxidant activity was $5.76 \mathrm{mg} / \mathrm{mL}$.

Based on these results, the PLE technique has been presented as an alternative in obtaining biocomposites with high added value, such as the blueberry by-products, reusing the agribusiness by-products with high antioxidant activity.

\subsection{PLE kinetics.}

Figure 2 presents the kinetics extraction yield for PLE with the Weibull model, elaborated from the yield data of each aliquot, for the different solvents used. The solvent ethylene glycol $20 \%$ demonstrated maximum extraction (439.85 mg blueberry by-products extract/g sample mass), followed by methanol $(376.90 \mathrm{mg} / \mathrm{g})$, ethanol $(337.45 \mathrm{mg} / \mathrm{g}$ ) and propylene glycol $20 \%(313.39 \mathrm{mg} / \mathrm{g})$. This difference in extract yield is possibly related to the affinity of the solvent with the compounds present in the matrix. Over time, the extraction rate decreases because the solvent needs to follow the capillary paths of the solid matrix to extract the compounds. 


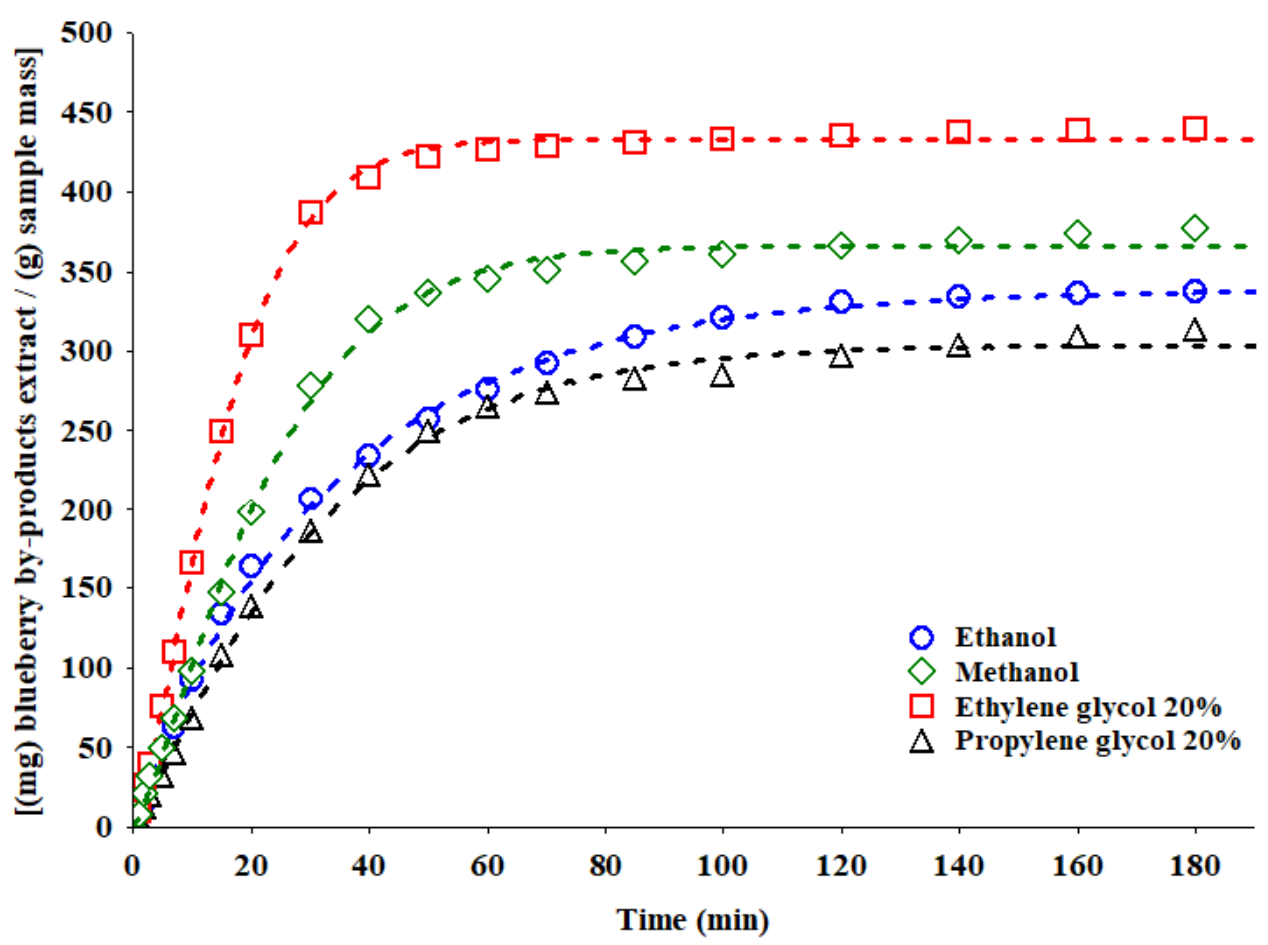

Figure 2. Kinetic extraction curves with different solvents. The dashed lines represent the Weibull model (Table 2).

The kinetic curves show a constant extraction rate between 0 and 40 min (CER period - constant extraction rate); decreasing extraction rate between 40 and $100 \mathrm{~min}$ (FER period falling extraction rate); and stability after $100 \mathrm{~min}$ until the end of the extraction (LER periodlow extraction rate or DC - diffusion-controlled). These different extraction periods are controlled by different mass transfer mechanisms, where convection predominates in the CER period; during FER starts the diffusion mechanism operating together with convection; and in the end, diffusion occurs mainly inside the solid particles, characterizing the LER or DC period [46].

According to Pereira and Meireles [47], the kinetic curves allow the evaluation of the mass transfer phenomena (convection and diffusion) and the thermodynamic limitations of the extraction process. In many applications, extraction can be completed initially, where most of the compounds of interest are obtained (50-90\% of the total yield). To determine the ideal extraction time, account should be taken not only of yield and bioactive properties but also of solvent consumption and economic factors.

\subsection{Total phenolic content (TPC).}

Figure 3 presents the yield of phenolic compounds analyzed in pooled aliquots every 30 min of extraction and PLE curves of total phenolic content (TPC) from blueberry byproducts with different solvents. In the initial $60 \mathrm{~min}$ of extraction, the largest amount of phenolic compounds was obtained (approximately $80.8 \%$ with ethanol, $74.2 \%$ with methanol, $77.7 \%$ with ethylene glycol $20 \%$, and $76.7 \%$ with propylene glycol $20 \%$ ) in the following times; the yield was significantly low. At the final time (180 min), extraction with propylene glycol 20\% showed the highest phenolic compound content, $4116.62 \pm 23.65 \mathrm{mg} \mathrm{GAE} / 100 \mathrm{~g}$ dr. 

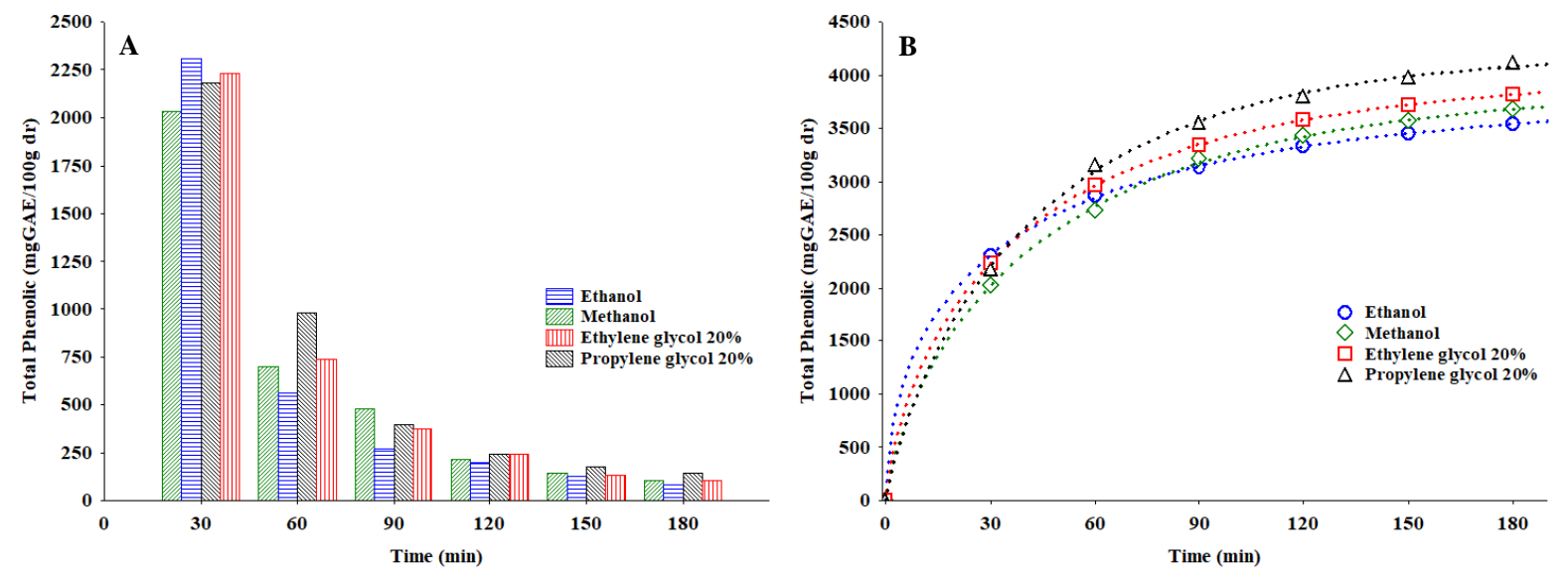

Figure 3. (A) Total phenolic content (TPC) every $30 \mathrm{~min}$; (B) PLE curves of total phenolic content (TPC) from blueberry by-products with different solvents. The dotted lines represent the Weibull model (Table 2).

\subsection{Monomeric anthocyanin content (MAC).}

Concerning the monomeric anthocyanin content (MAC), Figure 4 presents the yield of monomeric anthocyanin analyzed in pooled aliquots every 30 min of extraction and PLE curves of monomeric anthocyanin content (MAC) from blueberry by-products with different solvents. In the initial $60 \mathrm{~min}$ of extraction, the largest monomeric anthocyanin amount was obtained (approximately $84.3 \%$ with ethanol, $78.8 \%$ with methanol, $76.9 \%$ with ethylene glycol $20 \%$, and $72.3 \%$ with propylene glycol $20 \%$ ), in the following times, the yield was significantly low. At the final time (180 min), extraction with methanol showed the highest content of monomeric anthocyanin, $1036.65 \pm 16.05 \mathrm{mg} \mathrm{C} 3 \mathrm{GE} / 100 \mathrm{~g}$ dr.
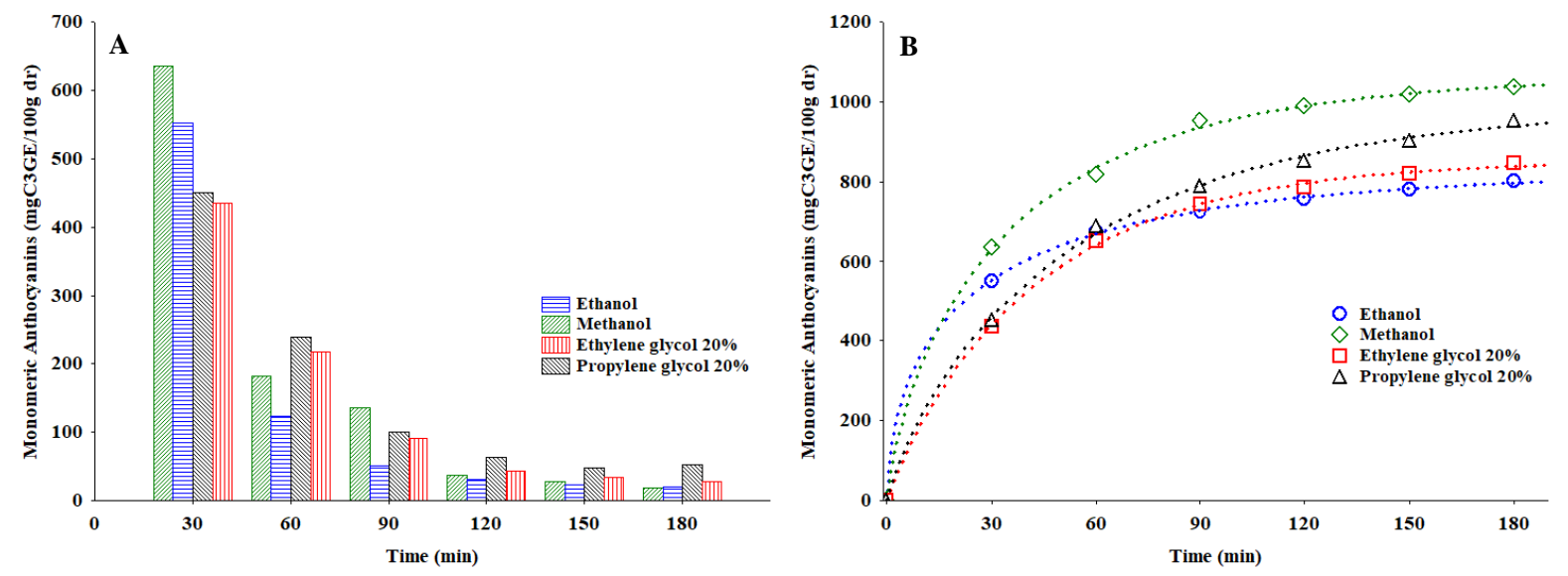

Figure 4.(A) Monomeric anthocyanin content (MAC) every $30 \mathrm{~min}$; (B) PLE curves of monomeric anthocyanin content (MAC) from blueberry by-products with different solvents. The dotted lines represent the Weibull model (Table 2).

\subsection{Antioxidant activity.}

The antioxidant activity of the blueberry extracts for the different solvents is present in Table 1. The best antioxidant activity was demonstrated by the extract obtained using propylene glycol $20 \%$ as a solvent, with $\mathrm{IC}_{50}$ of $0.11 \mathrm{mg} / \mathrm{mL}$ justified by the higher TPC.

All extracts by PLE presented good antioxidant activity. The total yield of the extraction does not influence the properties of the obtained extract since other compounds without any activity are also extracted. In a small yield, it is possible to obtain a high concentration of the compounds of interest. What influences the antioxidant activity of the extracts is the affinity and selectivity of the solvent with the bioactive compounds. PLE is a promising technique for 
extracting bioactive compounds since it reduces the time of the extraction process and energy cost and can be carried out at moderate temperatures. In addition, the use of PLE in industrial by-products, such as blueberry by-products, is a way of adding value in the extract with obtained bioactive compounds, which can be used in the food industry as an alternative to synthetic additives.

An example of the application of blueberry by-products extract is reported, Flores et al. [48] studied the encapsulation of blueberry pomace extract in whey proteins. The authors suggest that the spray-dried encapsulated powder can be a suitable food ingredient for health promotion.

\subsection{Kinetics models.}

The kinetic, TPC, and MAC curves were adjusted to Weibull and the power-law models, and the corresponding parameters of the models were listed in Table 2. According to the low values of the RMSE, the Weibull model adjusted well to the kinetic curves, TPC and MAC, ranging from 18.87 to 1.80 .

Table 2. Kinetic parameters for the Weibull and the power-law models for kinetic extraction, TPC, and MAC by PLE.

\begin{tabular}{|c|c|c|c|c|c|c|}
\hline \multirow{2}{*}{ Expression } & \multirow{2}{*}{ Model } & \multirow{2}{*}{ Parameters } & \multicolumn{4}{|c|}{ Solvent } \\
\hline & & & Ethanol & Methanol & Ethylene glycol 20\% & Propylene glycol 20\% \\
\hline \multirow{9}{*}{$\begin{array}{l}\text { Extraction } \\
\text { yield }\end{array}$} & \multirow{5}{*}{ Weibull } & A & 339.094 & 366.184 & 433.142 & 304.026 \\
\hline & & $\mathrm{k}$ & 0.0346 & 0.0173 & 0.0218 & 0.0202 \\
\hline & & $\mathrm{m}$ & 0.9597 & 1.2756 & 1.3517 & 1.1260 \\
\hline & & $\mathrm{R}^{2}$ & 99.885 & 99.845 & 99.957 & 99.858 \\
\hline & & RMSE & 4.26 & 5.78 & 3.56 & 4.47 \\
\hline & \multirow{4}{*}{ Power law } & $\mathrm{B}$ & 41.566 & 55.565 & 88.737 & 35.044 \\
\hline & & $\mathrm{n}$ & 0.4304 & 0.3996 & 0.3419 & 0.4484 \\
\hline & & $\mathrm{R}^{2}$ & 94.492 & 89.413 & 85.692 & 92.998 \\
\hline & & RMSE & 29.48 & 47.81 & 65.33 & 31.42 \\
\hline \multirow{9}{*}{ TPC } & \multirow{5}{*}{ Weibull } & $\mathrm{A}$ & 3868.316 & 3909.075 & 4038.582 & 4232.177 \\
\hline & & $\mathrm{k}$ & 0.1360 & 0.0548 & 0.0709 & 0.0420 \\
\hline & & $\mathrm{m}$ & 0.5585 & 0.7606 & 0.7147 & 0.8422 \\
\hline & & $\mathrm{R}^{2}$ & 99.997 & 99.973 & 99.998 & 99.994 \\
\hline & & RMSE & 3.74 & 11.69 & 2.94 & 18.87 \\
\hline & \multirow{4}{*}{ Power law } & $\mathrm{B}$ & 1091.083 & 747.325 & 910.418 & 814.865 \\
\hline & & $\mathrm{n}$ & 0.2305 & 0.3133 & 0.2818 & 0.3179 \\
\hline & & $\mathrm{R}^{2}$ & 99.781 & 99.362 & 99.483 & 99.073 \\
\hline & & RMSE & 31.94 & 57.16 & 53.29 & 77.09 \\
\hline \multirow{9}{*}{ MAC } & \multirow{5}{*}{ Weibull } & $\mathrm{A}$ & 838.351 & 1070.627 & 854.982 & 996.364 \\
\hline & & $\mathrm{k}$ & 0.1543 & 0.0652 & 0.0287 & 0.0336 \\
\hline & & $\mathrm{m}$ & 0.5723 & 0.7684 & 0.9480 & 0.8564 \\
\hline & & $\mathrm{R}^{2}$ & 99.986 & 99.917 & 99.944 & 99.875 \\
\hline & & RMSE & 1.80 & 5.87 & 3.94 & 6.50 \\
\hline & \multirow{4}{*}{ Power law } & $\mathrm{B}$ & 294.706 & 280.048 & 161.312 & 142.866 \\
\hline & & $\mathrm{n}$ & 0.1958 & 0.2591 & 0.3267 & 0.3702 \\
\hline & & $\mathrm{R}^{2}$ & 99.735 & 99.188 & 98.635 & 99.079 \\
\hline & & RMSE & 7.98 & 18.32 & 19.44 & 17.67 \\
\hline
\end{tabular}

\section{Conclusions}

The blueberry by-products are rich in bioactive compounds such as phenolic and anthocyanins. Using industrial by-products to obtain natural extracts using PLE is an 
alternative to conventional extraction techniques that use high temperatures. The products obtained in the extraction can be used in food instead of synthetic additives.

The extract yields of 31.33 to $48.98 \%(\mathrm{~m} / \mathrm{m})$ were obtained from PLE; the highest yield was obtained using ethylene glycol $20 \%(\mathrm{v} / \mathrm{v})$, in comparison with the extraction yield by maceration (8.84\%). The extracts present TPC between 3541.62 and $4116.62 \mathrm{mg} \mathrm{GAE} / 100 \mathrm{~g}$ dr; the propylene glycol $20 \%(\mathrm{v} / \mathrm{v})$ presented the highest content. The extracts present a MAC between 801.06 and $1036.65 \mathrm{mg} \mathrm{C} 3 \mathrm{CE} / 100 \mathrm{~g}$ dr; the methanol presented the highest content. By the PLE technique, excellent values of antioxidant activity ( $\mathrm{IC}_{50}$ ) were obtained, from 0.11 $\mathrm{mg} / \mathrm{mL}$ by extraction with propylene glycol $20 \%$ to $0.17 \mathrm{mg} / \mathrm{mL}$ with ethanol. As for ME, the antioxidant activity was $5.76 \mathrm{mg} / \mathrm{mL}$, justified by the higher content of extracted phenolic compounds. All extracts presented satisfactory antioxidant activity, and the PLE technique can be used to obtain biocomposite blueberry by-products.

The kinetic, TPC, and MAC curves were adjusted to Weibull and the power-law models. According to the low values of the RMSE, the Weibull model adjusted well to the kinetic curves, TPC and MAC, ranging from 18.87 to 1.80 .

The study of kinetic extraction curves suggests that the processing time can be reduced to $60 \mathrm{~min}$, where the largest fraction of compounds of interest is obtained, which results in lower costs. The solvent that presented the best antioxidant activity was propylene glycol $20 \%$ in an aqueous solution ( $\mathrm{v} / \mathrm{v})$, justified by the higher content of extracted phenolic compounds.

\section{Funding}

This study was financed by CAPES, Brazil [Financial Code 001].

\section{Acknowledgments}

Acknowledgments for National Council for Scientific and Technological Development (CNPq), Coordination for the Improvement of Higher Education Personnel (CAPES), and Research Support Foundation of the State of Rio Grande do Sul (FAPERGS).

\section{Conflicts of Interest}

The authors declare no conflict of interest.

\section{References}

1. Ravi, H.K.; Breil, C.; Vian, M.A.; Chemat, F.; Venskutonis, P.R. Biorefining of Bilberry (Vaccinium myrtillus L.) Pomace Using Microwave Hydrodiffusion and Gravity, Ultrasound-Assisted, and Bead-Milling Extraction. ACS Sustainable Chem. Eng 2018, 6, 4185-4193, https://doi.org/10.1021/acssuschemeng.7b04592.

2. Food and Agriculture Organization of the United Nations (FAO), http://www.fao.org/faostat/en/\#home (accessed April 16, 2021).

3. Wang, S.Y.; Camp, M.J.; Ehlenfeldt, M.K. Antioxidant capacity $\alpha$-glucosidase inhibitory activity in peel and flesh of blueberry (Vaccinium spp.) cultivars. Food Chemistry 2012, 132, 505-513, https://doi.org/10.1016/j.foodchem.2011.11.134.

4. Sarkis,J.R.; Jaeschke, D.P.; Tessaro, I.C.; Marczak, L.D.F. Effects of ohmic and conventional heating on anthocyanin degradation during the processing of blueberry pulp. LWT - Food Science and Technology 2013, 51, 79-85, https://doi.org/10.1016/j.lwt.2012.10.024.

5. Koutsoukos, S.; Tsiaka, T.; Tzani, A.; Zoumpoulakis, P.; Detsi, A. Choline chloride and tartaric acid, a Natural Deep Eutectic Solvent for the efficient extraction of phenolic and carotenoid compounds. Journal of Cleaner Production 2019, 241, https://doi.org/10.1016/j.jclepro.2019.118384. 
6. Lee, J.. Finn, C.E.. Wrolstad, R.E. Anthocyanin pigment and total phenolic content of three Vaccinium species native to the Pacific Northwest of North America. HortScience 2004, 39, 959-964, https://doi.org/10.21273/HORTSCI.39.5.959.

7. Khalifa, H.O.; Kamimoto, M.; Shimamoto, T.; Shimamoto, T. Antimicrobial effects of blueberry, raspberry, and strawberry aqueous extracts and their effects on virulence gene expression in Vibrio cholerae. Phytotherapy Research 2015, 29, 1791-1797, https://doi.org/10.1002/ptr.5436.

8. Péres-Jiménes, J.; Arranz, S.; Tabernero, M.; Diazrubio, M.E.; Serrano, J.; Gono, I.; Saura-Calixto, F. Update methodology to determine antioxidant capacity in plant, food, oils and beverages: extraction measurement and expression of results. Food Research International 2008, 41, 274-285, https://doi.org/10.1016/j.foodres.2007.12.004.

9. Mendiola, J.A.; Jaime, L.; Santoyom S.; Reglero, G.; Cifuentes, A.; Ibañez, E.; Señoráns, F. J. Screening of functional compounds in supercritical fluid extracts from Spirulina platensis. Food Chemistry 2007, 102, 1357-1367, https://doi.org/10.1016/j.foodchem.2006.06.068.

10. Paes,J.; Dotta,R.; Barbero,G.F.; Martínez, J. Extraction of phenolic compounds and anthocyanins from blueberry (Vaccinium myrtillus L.) residues using supercritical $\mathrm{CO}_{2}$ and pressurized liquids. The Journal of Supercritical Fluids 2014, 95, 8-16, https://doi.org/10.1016/j.supflu.2014.07.025.

11. Rodríguez-Sánchez, S.; Ruiz-Aceituno, L.; Sanz, M.L.; Soria, A.C. New Methodologies for the Extraction and Fractionation of Bioactive Carbohydrates from Mulberry (Morus alba) Leaves. Journal of Agricultural and Food Chemistry 2013, 61, 4539-4545, https://doi.org/10.1021/jf305049k.

12. Barrales, F.M.; Silveira, P.; Barbosa, P.P.M.; Ruviaro, A.R.; Paulino, B.N.; Pastore, G. M.; Macedo, G.A.; Martinez, J. Recovery of phenolic compounds from citrus by-products using pressurized liquids - An application to orange peel. Food and Bioproducts Processing 2018, 112, 9-21, https://doi.org/10.1016/j.fbp.2018.08.006.

13. Figueroa, J.G.; Borrás-Linares, I.; Lozano-Sánchez, J.; Quirantes-Piné, R.; Segura-Carretero, A. Optimization of drying process and pressurized liquid extraction for recovery of bioactive compounds from avocado peel by-product. ELECTROPHORESIS 2018, 39, 1908-1916, https://doi.org/10.1002/elps.201700379.

14. Okiyama, D.C.G.; Soares, I.D.; Cuevas, M.S.; Crevelin, E.J.; Moraes, L.A.B.; Melo, M.P.; Oliveira, A.L.; Rodrigues, C.E.C. Pressurized liquid extraction of flavanols and alkaloids from cocoa bean shell using ethanol as solvent. Food Research International 2018, 114, 20-29, https://doi.org/10.1016/j.foodres.2018.07.055.

15. Ballesteros-Vivas, D.; Álvarez-Rivera, G.; Morantes, S.J.; Sánchez-Camargo, A.P.; Ibáñez, E.; ParadaAlfonso, F.; Cifuentes, A. An integrated approach for the valorization of mango seed kernel: Efficient extraction solvent selection, phytochemical profiling and antiproliferative activity assessment. Food Research International 2019, 126, https://doi.org/10.1016/j.foodres.2019.108616.

16. Rosa, A.D.; Junges, A.; Fernandes, I.A.; Cansian, R.L.; Corazza, M.L.; Franceschi, E.; Backes, G.T.; Valduga, E. High pressure extraction of olive leaves (Olea europaea): bioactive compounds, bioactivity and kinetic modelling. J Food Sci Technol 2019, 56, 3864-3876, https://doi.org/10.1007/s13197-019-03856-w.

17. Bobinaitè, R.; Kraujalis, P.; Tamkutè, L.; Urbonavičienè, D.; Viškelis, P.; Venskutonis, P.R. Recovery of bioactive substances from rowanberry pomace by consecutive extraction with supercritical carbon dioxide and pressurized solvents. Journal of Industrial and Engineering Chemistry 2020, 85, 152-160, https://doi.org/10.1016/j.jiec.2020.01.036.

18. Hirondart, M.; Rombaut, N.; Fabiano-Tixier, A.S.; Bily, A.; Chemat, F. Comparison between Pressurized Liquid Extraction and Conventional Soxhlet Extraction for Rosemary Antioxidants, Yield, Composition, and Environmental Footprint. Foods 2020, 9, https://doi.org/10.3390/foods9050584.

19. Hernández-Corroto, E.; Plaza, M.; Marina, M.L.; García, M.C. Sustainable extraction of proteins and bioactive substances from pomegranate peel (Punica granatum L.) using pressurized liquids and deep eutectic solvents. Innovative Food Science \& Emerging Technologies 2020, 60, https://doi.org/10.1016/j.ifset.2020.102314.

20. Kitryte, V.; Kavaliauskaitè, A.; Tamkute, L.; Pukalskienè, M.; Syrpas, M.; Venskutonis, P.R. Zero waste biorefining of lingonberry (Vaccinium vitis-idaea L.) pomace into functional ingredients by consecutive high pressure and enzyme assisted extractions with green solvents. Food Chemistry 2020, 322, https://doi.org/10.1016/j.foodchem.2020.126767.

21. Nastić, N.; Lozano-Sánchez, J.; Borrás-Linares, I.; Švarc-Gajić, J.; Segura-Carretero, A. New technological approaches for recovering bioactive food constituents from sweet cherry (Prunus avium L.) stems. Phytochemical Analysis 2020, 31, 119-130, https://doi.org/10.1002/pca.2872.

22. Pereira, D.T.V.; Marson, G.V.; Barbero, G.F.; Tarone, A.G.; Cazarin, C.B.B.; Hubinger, M.D.; Martínez, J. Concentration of bioactive compounds from grape marc using pressurized liquid extraction followed by 
integrated membrane processes. Separation and Purification Technology 2020, 250, https://doi.org/10.1016/j.seppur.2020.117206.

23. Tamkutè, L.; Liepuoniūtè, R.; Pukalskienè, M.; Venskutonis, P.R. Recovery of valuable lipophilic and polyphenolic fractions from cranberry pomace by consecutive supercritical $\mathrm{CO}_{2}$ and pressurized liquid extraction. The Journal of Supercritical Fluids 2020, 159, https://doi.org/10.1016/j.supflu.2020.104755.

24. Zandoná, G.P.; Bagatini, L.; Woloszyn, N.; Cardoso, J.S.; Hoffmann, J.F.; Moroni, L.S.; Stefanello, F.M.; Junges, A.; Rombaldi, C.V. Extraction and characterization of phytochemical compounds from araçazeiro (Psidium cattleianum) leaf: Putative antioxidant and antimicrobial properties. Food Research International 2020, 137, https://doi.org/10.1016/j.foodres.2020.109573.

25. Santos, P.H.; Kammers, J.C.; Silva, A.P.; Oliveira, J.V.; Hense, H. Antioxidant and antibacterial compounds from feijoa leaf extracts obtained by pressurized liquid extraction and supercritical fluid extraction. Food Chemistry 2021, 344, https://doi.org/10.1016/j.foodchem.2020.128620.

26. Pereira, D.T.V.; Zabot,G.L.; Reyes, F.G.R.; Iglesias, A.H.; Martínez, J. Integration of pressurized liquids and ultrasound in the extraction of bioactive compounds from passion fruit rinds: Impact on phenolic yield, extraction kinetics and technical-economic evaluation. Innovative Food Science \& Emerging Technologies 2021, 67, https://doi.org/10.1016/j.ifset.2020.102549.

27. Wijngaard, H.; Brunton, N. The Optimization of Extraction of Antioxidants from Apple Pomace by Pressurized Liquids. Journal of Agricultural and Food Chemistry 2009, 57, 10625-10631, https://doi.org/10.1021/jf902498y.

28. Silva, L.C.; Souza, M.C.; Sumere, B.R.; Silva, L.G.S.; Cunha, D.T.; Barbero, G.F.; Bezerra, R.M.N.; Rostagno, M.A. Simultaneous extraction and separation of bioactive compounds from apple pomace using pressurized liquids coupled on-line with solid-phase extraction. Food Chemistry 2020, 318, https://doi.org/10.1016/j.foodchem.2020.126450.

29. Souza, M.C.; Silva, L.C.; Chaves, J.O.; Salvador, M.P.; Sanches, V.L.; Cunha, D.T.; Carneiro, T.F.; Rostagno, M.A. Simultaneous extraction and separation of compounds from mate (Ilex paraguariensis) leaves by pressurized liquid extraction coupled with solid-phase extraction and in-line UV detection. Food Chemistry: Molecular Sciences 2021, 2, https://doi.org/10.1016/j.fochms.2020.100008.

30. Vega, G.C.; Sohn, J.; Voogt, J.; Birkved, M.; Olsen, S.I.; Nilsson, A.E. Insights from combining technoeconomic and life cycle assessment - a case study of polyphenol extraction from red wine pomace. Resources, Conservation and Recycling 2021, 167, https://doi.org/10.1016/j.resconrec.2020.105318.

31. Instituto Adolfo Lutz. Métodos físico-químicos para análise de alimentos. 4rd ed. São Paulo: Instituto Adolfo Lutz, 2008, 1020.

32. Garcia-Amoedo, L. H.; Almeida-Muradian, L. B. Comparação de metodologias para determinação de umidade em geléia real. Química Nova 2002, 25, 676-679, http://dx.doi.org/10.1590/S0100-40422002000400024.

33. Singleton, V.L.; Orthofer, R.; Lamuela-Raventós, R.M. Analysis of total phenols and other oxidation substrates and antioxidants by means of folin-ciocalteu reagent. Methods in Enzymology 1999, 229, 152-178, https://doi.org/10.1016/S0076-6879(99)99017-1.

34. Lee, J.; Durst, R.W.; Wrolstad, R.E. Determination of Total Monomeric Anthocyanin Pigment Content of Fruit Juices, Beverages, Natural Colorants, and Wines by the pH Differential Method: Collaborative Study. Journal of AOAC INTERNATIONAL 2005, 88, 1269-1278, https://doi.org/10.1093/jaoac/88.5.1269.

35. Brand-Williams, W.; Culiver M.E.; Berset, C. Use of a free radical method to evaluate antioxidant activity. LWT - Food Science and Tecnology 1995, 28, 25-30, https://doi.org/10.1016/S0023-6438(95)80008-5.

36. Cheung, Y.; Wu, J. Kinetic models and process parameters for ultrasound-assisted extraction of water-soluble components and polysaccharides from a medicinal fungus. Biochemical Engineering Journal 2013, 79, 214220, https://doi.org/10.1016/j.bej.2013.08.009.

37. Sant'Anna, V.; Marczak, L.D.F.; Tessaro, I.C. Kinetic Modeling of Anthocyanin Extraction from Grape Marc. Food Bioprocess Technol 2013, 6, 3473-3480, https://doi.org/10.1007/s11947-012-1016-1.

38. Rodríguez, Ó.; Ortuño, C.; Simal, S.; Benedito, J.; Femenia, A.; Rosselló,C. Acoustically assisted supercritical $\mathrm{CO}_{2}$ extraction of cocoa butter: Effects on kinetics and quality. The Journal of Supercritical Fluids 2014, 94, 30-37, https://doi.org/10.1016/j.supflu.2014.06.017.

39. Kim, T.W.; Kim, JH. Kinetics and thermodynamics of paclitaxel extraction from plant cell culture. Korean J. Chem. Eng. 2016, 33, 3175-3183, https://doi.org/10.1007/s11814-016-0187-2.

40. Caballero-Galván, A.S.; Restrepo-Serna, D.L.; Ortiz-Sánchez, M.; Cardona-Alzate, C.A. Analysis of Extraction Kinetics of Bioactive Compounds from Spent Coffee Grounds (Coffea arábica). Waste Biomass Valor 2018, 9, 2381-2389, https://doi.org/10.1007/s12649-018-0332-8. 
41. Jesus, A.L.T.; Cristianini, M.; Santos, N.M.; Júnior,M.R.M. Effects of high hydrostatic pressure on the microbial inactivation and extraction of bioactive compounds from açaí (Euterpe oleracea Martius) pulp. Food Research International 2020, 130, https://doi.org/10.1016/j.foodres.2019.108856.

42. Kashaninejad, M.; Sanz, M.T.; Blanco, B.; Beltrán, S.; Niknam, S.M. Freeze dried extract from olive leaves: Valorisation, extraction kinetics and extract characterization. Food and Bioproducts Processing 2020, 124, 196-207, https://doi.org/10.1016/j.fbp.2020.08.015.

43. Natolino, A.; Porto, C. Kinetic models for conventional and ultrasound assistant extraction of polyphenols from defatted fresh and distilled grape marc and its main components skins and seeds. Chemical Engineering Research and Design 2020, 156, https://doi.org/10.1016/j.cherd.2020.01.009.

44. Valverde, A.; Alvarez-Florez, J.; Recasens, F. Hybrid nonlinear autoregressive neural network-Weibull statistical model applied to the supercritical extraction of lanolin from raw wool. SN Appl. Sci. 2020, 2 , https://doi.org/10.1007/s42452-020-03475-7.

45. Trigueros, E.; Sanz, M.T.; Filipigh, A.; Beltrán, S.; Riaño, P. Enzymatic hydrolysis of the industrial solid residue of red seaweed after agar extraction: Extracts characterization and modelling. Food and Bioproducts Processing 2021, 126, 356-366, https://doi.org/10.1016/j.fbp.2021.01.014.

46. Da Silva, R.P.F.F.; Rocha-Santos, T.A.P.; Duarte, A.C. Supercritical fluid extraction of bioactive compounds. TrAC Trends in Analytical Chemistry 2016, 76, 40-51, https://doi.org/10.1016/j.trac.2015.11.013.

47.Pereira, C.G.; Meireles, M.A.A. Supercritical fluid extraction of bioactive compounds: fundamentals, applications and economic perspectives. Food and Bioprocess Technology 2010, 3, 340-372, https://doi.org/10.1007/s11947-009-0263-2.

48. Flores, F.P. Singh, R.K.; Kong, Fanbin. Physical and storage properties of spray-dried blueberry pomace extract with whey protein isolate as wall material. Journal of Food Engineering 2014, 137, 1-6, https://doi.org/10.1016/j.jfoodeng.2014.03.034. 